\title{
LANGUAGE AND COMPUTERS
}

Vol. 3. Pieter de Haan: Postmodifying Clauses in the English Noun Phrase. A Corpus-Based Study. Amsterdam/Atlanta GA 1989. 252 pp.

ISBN: 90-5183-123-4.

Hfl. 75,-/US- $\$ 37.50$

The study aims at a description of the most important characteristics of postmodifying clauses (PMCs) in the English noun phrase (NP). The author discusses these, and the relationships obtaining among them, on the basis of an examination of a corpus of English texts. The first two chapters are devoted to a detailed description of the structure of the NP more generally, and the PMC in particular. Both finite and non-finite clauses are discussed. The emphasis is on such matters as clause patterns in the PMC, type and function of the linkword, type and function of the NP, and type, form and position of the PMC.

\section{LANGUAGE AND COMPUTERS}

Vol. 4. Theory and Practice in Corpus Linguistics. Eds. Jan Aarts \& Willem Meijs. Amsterdam/Atlanta GA 1990. III,254 pp.

ISBN: 90-5183-174-9.

Hfl. $75,-/$ US- $\$ 37.50$

Contents: B. Altenberg \& M. Eeg Olofsson: Phraseology in spoken English: presentation of a project. T. Briscoe: English noun phrases are regular: a reply to professor Sampson. N. Belmore: Working with Brown and LOB on a microcomputer. W. Campbell: Measuring speech-rate in the spoken English corpus. O. Ihalainen: A source of data for the study of English dialectal syntax: the Helsinki corpus. S. Janssen: Automatic sense disambiguation with LDOCE. G. Kaye: A corpus builder and real-time concordance browser for an IBM pc. G. Kjellmer: Patterns of collocability. C. Souter: Systemicfunctional grammars and corpora. A. Stenström: What is the role of discourse signals in sentence grammar? K. Wikberg: Topic, theme and hierarchical structure in procedural discourse.

USA/Canada: Editions Rodopi, 233 Peachtree Street, N.E., Suite 404, Atlanta, Ga. 303031504, Telephone (404) 523-1964, only USA 1-800-225-3998, Fax (404) - 522-7116 And Others: Editions Rodopi B.V., Keizersgracht 302-304, 1016 EX Amsterdam, Telephone (020) -22.75 .07 , Fax (020) -38.09 .48$ 


\section{LANGUAGE AND COGNITIVE PROCESSES}

\section{Managing Editors}

Lorraine K.Tyler, University of Cambridge, UK (Coordinating Editor)

Brian Butterworth, University of London, $U K$

Philip Johnson-Laird, MRC Applied Psychology Unit, Cambridge, UK

William Marslen-Wilson, MRC Applied Psychology Unit, Cambridge, UK

Mark Steedman, University of Edinburgh, UK

Michael Tanenhaus, University of Rochester, USA

Language and Cognitive Processes provides an intemational forum for the publication of theoretical and experimental research into the mental processes and representations involved in language use. Research relevant to the psychological theory of language stems from a wide variety of disciplines and the content of Langucge and Cognitive Processes reflects this interdisciplinary perspective. Apart from research in experimental and developmental psychology, Language and Cognitive Processes publishes work derived from linguistics, philosophy, computer science, and $\mathrm{AI}$.

"... I hope Language and Cognitive Processes continues to maintain the high standard of its opening few issues and establishes a place for itself under the academic sun..."

Times Higher Education Supplement.

\section{SPECIAL ISSUES}

Forthcoming special issue: Parsing and Interpretation, edited by Gerry Altmann

\section{SUBSCRIPTION INFORMATION}

Subscription rates for volume 5 (4 issues), 1990

Institutions

ISSN 01690965

Individuals

\section{ORDER FORM}

Complete and retum to: Lawrence Erlbaum Associates, 27 Palmeira Mansions, Church Road, Hove, East Sussex, BN3 2FA, England

Name

Address

$\square$ Enter my subscription to Language and Cognitive Processes, volume 5 (1990)

Payment method: Access/Mastercard VISA Amex Cheque Circle as appropriate

Credit Card number

Expiry date Signature

Choques should be made payable to The Distribution Centre and should be in $f$ sterling or USS drawn on a UK bank. Eurocheques cannot be accepted. 


\section{\& Language Variation and Change}

\section{NOTES FOR CONTRIBUTORS}

Language Variation and Change publishes original research reports that are based on data of language production, either oral or written, from contemporary or historical sources. Articles with substantive content are preferred over those that are solely argumentative; those that synthesize or reanalyze a number of research findings on substantive issues will also be considered. Conforming to scientific methodology, the reported findings should be fully replicable from the information provided.

Contributions may be submitted from all countries. The usual language of publication is English, although articles in French are also welcome. All submissions should be sent, in triplicate, to:

David Sankoff

Language Variation and Change

Centre de recherches mathématiques

Université de Montréal

C.P. 6128, Succursale "A"

Montréal H3C 3J7, Canada

Submission of an article is taken to imply that it has not been previously published or is not being considered for publication elsewhere. If an author is publishing a related article, this fact should be stated.

Copyright. Contributors of accepted articles will be asked to assign their copyrights, on certain conditions, to Cambridge University Press, to help protect their material, particularly in the U.S.A.

\section{Manuscript Preparation and Style}

Manuscripts should be clearly typed on $81 / 2 " \times 11^{11}$ or A4 white bond paper. The inclusion of microcomputer diskettes containing text, artwork, and appropriate software, along with the hard copy, may facilitate editing. The entire manuscript - including abstract, references, and tables - must be double-spaced and numbered consecutively. The Editor may find it necessary to return manuscripts for reworking or retyping that do not conform to the journal's requirements. The article should be arranged as follows:

Title Page (page 1). To facilitate blind reviews, all indication of authorship must be limited to this page. Other pages must only show the short title plus page number in the upper right corner. The title page includes (a) full title, (b) names and affiliations of all authors, (c) mailing address and phone number of the lead author, (d) address to which offprints should be sent (if not the lead author), (e) short title of less than 50 characters.

Abstract (page 2). Include the full title and the abstract. Abstracts should not exceed 150 words.

Acknowledgments (page 2). Place below the abstract. Use this section to indicate any grant support, substantial assistance in the preparation of the article, or any other author notes.

Text (page 3). Use a 5-character paragraph indent. Do not hyphenate words or justify the right margin. Underscore material that is to be italicized in print. Glosses should be placed within single quotation marks.
References are to be made in the text (not in the endnotes) by giving in parentheses the name of the author, year of publication, and where relevant, the page(s) referred to: (Vincent, 1982:90-91). If the author's name is part of the text, the following form should be used: "Vincent (1982) listed several. . . ." For multi-authored works, only the first citation should list all authors: (Weinreich, Labov, \& Herzog, 1968). In subsequent citations, only the first name should be given, followed by "et al.": (Weinreich et al., 1968). Separate works referred to in the same parentheses should be listed in alphabetical order; those by the same author should be separated by commas, and those by different authors by semi-colons: (López Morales, 1981; Vincent, 1981, 1982). Initials should be used (before the author's name) only when it is necessary to distinguish between two or more authors with the same surname referred to in the same article.

All works referred to in the text must be listed in the reference section, double-spaced and in alphabetical order.

Examples of references (note the use of punctuation marks within references):

Cedergren, Henrietta J. (1973). Interplay of social and linguistic factors in Panama. Ph.D. dissertation, Cornell University.

López Morales, Humberto. (1981). Velarization of $/ \mathrm{n} /$ in Puerto Rican Spanish. In D. Sankoff \& H. J. Cedergren (eds.), Variation omnibus. Edmonton: Linguistic Research, Inc. 105-113.

Tagliamonte, Sali, \& Poplack, Shana. (1980). How Black English Past got to the present: Evidence from Samaná. Language in Society 17:513-533.

Vincent, Diane. (1982). Pressions et impressions sur les sacres au Québec. Montréal: Office de la langue française.

Tables. Tables must appear as a unit following the reference section. Each table should be typed, doublespaced, on a separate sheet, numbered consecutively with an Arabic numeral and a short title. All tables must be cited in the text.

Figures. Figures must appear as a unit following the tables. Figures must be ready for photographic reproduction: for photographs, an 8" $\times 11$ " glossy; or for diagrams, professionally-rendered or computer-generated. All labels and details must be clearly printed and large enough to remain legible at a $50 \%$ reduction. Each figure must be numbered consecutively with an Arabic number. Descriptive legends must be typed together, double-spaced, on a separate sheet preceding the artwork. Artwork should be identified by number and title on the back and be carefully packaged in a protective envelope. All figures must be cited in the text.

Proofs

First proofs will be sent to the lead author who will be expected to correct and return them to the Editor, by airmail where appropriate, within three days of receipt.

\section{Offprints}

25 offprints of the article will be provided free of charge to the lead author. Additional offprints may be purchased if ordered at the proos stage. 


\section{< Language Variation and Change}

Volume 2 Number 11990

\section{CONTENTS}

Gregory R. Guy and Sally Boyd

The development of a morphological class

Nuria Alturo and Ma. Teresa Turell

Linguistic change in El Pont de Suert: The study of variation of $/ 3 /$

Rajend Mesthrie and Timothy T. Dunne

Syntactic variation in language shift: The relative clause in South African Indian English

\section{Rosa Saladino}

Language shift in standard Italian and dialect: A case study

David Sankoff, Shana Poplack, and Swathi Vanniarajan

The case of the nonce loan in Tamil 